Social Work \& Education

УДК [37.034:159.964.21]:316.77

DOI: $10.25128 / 2520-6230.19 .3 .6$
(๑) SW\&E, 2019

Жаровська, О. (2019). Технології соціального проектування у підготовці фахівців соціономічних професій. Social Work and Education. Vol. 6, No. 3. Ternopil-Aberdeen, 2019. pp. 285-295. DOI: 10.25128/2520-6230.19.3.6

\section{ТЕХНОЛОГІЇ СОЦІАЛЬНОГО ПРОЕКТУВАННЯ У ПІДГОТОВЦІ ФАХІВЦІВ СОЦІОНОМІЧНИХ ПРОФЕСІЙ}

\section{Олена Жаровська,}

кандидат педагогічних наук, доиент кафедри психологопедагогічної освіти та

соиіальних наук, КВНЗ «Вінницької академіі неперервної освіти», м. Вінниця, Україна mova_m@ukr.net

Article history:

Received: March 28, 2019

1st Revision: June 12, 2019

Accepted: September 30, 2019
АНОТАЦІЯ. У статті обгрунтовано необхідність узагальнення та систематизації наукових уявлень про проектування, отриманих у проблемному полі соціальної роботи як науки 3 метою подальшого впровадження соціального проектування у підготовку фахівців соціономічних професій. У дослідженні за основу взято визначення проектування як конструювання варіантів оптимального майбутнього стану об'єкта 3 метою прийняття рішень в умовах невизначеності. Мета статті полягає у тому, щоб схарактеризувати особливості впровадження технології соціального проектування у підготовку фахівців соціономічних професій. Методи дослідження - аналіз, синтез, порівняння. У статті закцентовано увагу на основну мету соціальних проектів, котрі забезпечують інтеграцію фундаментальних знань та практичної діяльності в освітньому процесі вищої школи. До базових ознак соціальних проектів зараховують цілепокладання; соціальну детермінацію, часову, територіальну, соціально-інституційну, інноваційну, ресурсну, організаційну, соціально-інформаційну. У статті звертається увага на те, що в основу соціального проектування мають бути закладені такі параметри: суперечливість соціального об'єкту; багатовекторність розвитку соціального об'єкту; множинність факторів його буття; суб'єктивні складові формування соціального очікування та прогнозу; фактори, що визначають різні критерії оцінки соціального об'єкту. Серед основних факторів соціокультурного проектування виокремлюють проектну культуру, котра визначається як єдність знань, здібностей до проектування, цінностей, цілей, управлінських та організаційних відносин, прояви соціальної активності та творчої проектної діяльності, спрямованої на вирішення соціально значущих проблем.

Ключові слова: соціальне проектування; технологія проекту; соціальна робота; проектна культура; соціономічні професії. 


\section{Вступ}

Реформування вищої освіти в Україні має відбуватися за підтримки державою науки й пріоритетних напрямів освіти, приведенням у відповідність вітчизняних стандартів до новітніх світових досягнень. Нинішній стан розвитку освіти залежить безпосередньо від ринкових відносин, тому доцільно реформувати освітню галузь 3 моделей, програм, змісту та освітніх технологій, котрі сприятимуть появі фахівців нового типу, здатних обирати оптимальні шляхи розв'язання проблемних ситуацій та досягнення стратегічних цілей. Такі виклики стоять в першу чергу перед фахівцями соціономічних професій, оскільки забезпечують взаємодію типу «людина-людина», «людина-соціум».

Серед актуальних проблем розвитку та реформування сучасної освіти дослідники виокремлюють (Дронова, 2004): аналіз потенціалу освітніх закладів держави, зокрема закладів вищої освіти та потреб різних галузей у фахівцях певної кваліфікації, впровадження та використання методик визначення потреб держави у кваліфікованих працівниках (враховуючи ринкову ситуацію). Технології соціального проектування сприятимуть реформуванню усіх сфер суспільства, в тому числі й освітньої галузі (Нагорна, 2016). Освітні проекти висвітлюють завдання, переважно пов'язані з наданням освітніх послуг. Так, В. Луков зауважує, що придбання знань, умінь і навичок характерно для будьякого соціального проекту, тут же такого роду досягнення є основною метою соціально-проектної діяльності. Освітні проекти повинні бути спрямовані на вдосконалення самої системи освіти (Луков, 2003). Особливої актуальності технологія соціального проектування набуває серед професій соціономічного типу, це професії суб'єкт-суб'єктного типу, предметом вивчення, зміни, розвитку і обслуговування яких є люди різного віку, групи населення, спільноти і цілі соціальні системи (Prushlyak, 2016). Суб'єктом та об’єктом уваги є людина. Між суб'єктом і об'єктом складаються особливі людські відносини, а основна праця витрачається на взаємодію між ними. До цієї групи належать усі професії сфери управління, послуг, педагогічні, медичні професії та інші.

\section{Аналіз останніх публікацій}

Публікації останніх років підтверджують теорію про трансформація стилю роботи і мислення людей, котрі певною мірою вимагають нових інструментів оновлення суспільства, активізації людського фактору, вирішення цілого комплексу проблем в економічній, соціальній, політичній сферах, сфері духовного життя. Так, соціальне проектування $€$ однією 3 інноваційних соціальних технологій, котра активно застосовується в останні десятиліття та активно впроваджується в освітній процес закладів вищої освіти. 
Питання та шляхи впровадження соціального проектування у структуру професійної підготовки майбутніх фахівців висвітлено у дослідженнях О. Безпалько, Д. Бибик, М. Бірюкової, В. Лукова, Г. Нагорної, М. Роганової. На думку М. Бірюкової, соціальне проектування - актуалізація практичної ситуації і усвідомлення індивідом, групою або організацією поля перспективних бажань, вироблення спектру оптимальних образів майбутнього i вибір суб'єктом найкращого проекту i технологій його реалізації з урахуванням умов, часу $\mathrm{i}$ ресурсів (Бірюкова, 2001).

Враховуючи упровадження технології проектування у різних видах суспільної діяльності (виробництві, політиці, мистецтві тощо), виокремлення його в самостійну технологію, не можна оминути проблеми його застосування в соціальній роботі. Серед актуальних питань, котрі потребують висвітлення дослідники виокремлюють такі: урахування значущості проектування для соціальної роботи як науки 3 соціальною роботою як практичною діяльністю; застосування проектування, методу проектів у підготовці фахівців із соціальної роботи; необхідність узагальнення та систематизації наукових уявлень про проектування, отриманих у проблемному полі соціальної роботи як науки (Бибик, 2016). Науковці зауважують, що ступінь сформованості духовних, моральних, громадянських якостей студентів виявляється через їхню свідому участь у розробці та захисті різноманітних соціальних проектів (Роганова, 2016). Однією 3 характерних особливостей соціального проектування стає «громадська участь», громадська залученість в процеси соціальних змін, соціально проектна діяльність починає розглядатися не тільки як результат державної політики, а й як діяльність громадських організацій, як єдиний простір взаємодії соціальних партнерів.

Мета статті - схарактеризувати технології соціального проектування у підготовці фахівців соціономічних професій.

Завдання дослідження: (1) з'ясувати роль та місце методу проектування в освітньому процесі вищої школи; (2) з'ясувати фактори впливу соціального проектування на освітне середовище закладу вищої освіти.

\section{Методологія дослідження}

Для досягнення мети було використано наступні методи: аналіз (виокремлення основних етапів соціального проектування 3 метою ї детального вивчення), синтез (об'єднання виокремлених ознак соціального проектування та їх систематизація 3 метою подальшого впровадження у підготовці фахівців соціономічних професій), узагальнення (виокремлення загальних ознак соціокультурного проектування та певних його характеристик з метою переходу 
від теоретичного осмислення до практичного впровадження в освітній процес закладів вищої освіти).

\section{Основна частина}

Упровадження соціальних проектів у культурно-освітньо-виховному просторі навчального закладу вирішує систему цілей: виховати сучасного студента як громадянина, професіонала, високоморальну, інтелігентну, творчу, особистість, як людину Культури. Завдання в цьому напрямку освітньо-вихованої роботи спрямовані на: формування громадянської свідомості, патріотичних почуттів; виховання особистості демократичного світогляду й культури; забезпечення умов для самореалізації особистості відповідно до їі здібностей, суспільних та власних інтересів; створення й розвиток цінностей суспільства; розробку виховних програм, спрямованих на формування духовної культури (Роганова, 2019).

Унікальність освітніх проектів зумовлено саме його продуктом, який одночасно виступає одним 3 замовників. В фазах ініціювання та планування освітнього проекту особа, яка бажає навчатися, витупає в ролі замовника та «сировини» - абітурієнта, під час реалізації проекту та ж сама особа є продуктом, виконуючим роботи, і замовником, який відстежує задоволення власних потреб, в фазі завершення проекту продукт стає випускником, який в ролі замовника приймає рішення про задоволення визначених при плануванні проекту вимог.

Крім безпосередньо продукту для освітніх проектів властива наявність ще двох замовників: держави (суспільства) i конкретного замовника-працедавця (підприємець, який має потребу у спеціалістах). Вимоги замовників у сукупності характеризуються динамічною складністю та зводяться до поповнення суспільства всебічно та гармонійно розвинутою особистістю здатною до саморозвитку та підвищення ефективності діяльності будь-якої організації (підприємства, фірми, тощо). В освітніх проектах арсенал корегуючих дій, які втілюються для досягнення поставленої мети в області якості, дуже специфічний i значно менший ніж в проектах взагалі, що обумовлене специфікою продукту таких проектів (Борзенко-Мірошніченко, 2007).

3 розвитком суспільства відбулися помітні зміни у системі соціального виховання, зокрема зменшився вплив сім’ї у формуванні соціальної складової. У науковому дискурсі звертається увага на мету соціального виховання стосовно різних соціальних груп, акцентується увага на культуро відповідності соціального виховання, висвітлюється ідея особистісного розвитку людини, створюється методика соціального виховання індивіда; пропонуються моделі соціального виховання на рівні макро- та мікросоціуму (Рижанова, 2005).

Науковці (Безпалько, 2010) розглядають проектування як: «визначення версій чи варіантів розвитку або зміни певного явища чи об'єкту; конструювання 
варіантів оптимального майбутнього стану об’єкту; форма випереджального відображення і перетворення дійсності, спрямована на конструювання системи параметрів майбутнього матеріального об'єкту чи якісно нового його стану; прийняття рішень в умовах невизначеності».

За визначенням науковців (Тюптя, Іванова, 2019), соціальний проект - це сконструйоване ініціатором проекту соціальне нововведення, метою якого $\epsilon$ створення, модернізація або підтримання у середовищі, що змінюється, матеріальної або духовної цінності. Це нововведення мусить мати просторовочасові координати, а його вплив на людей - визнаватися позитивним за соціальним значенням. Але найчастіше соціальне проектування не дає бажаних результатів. Цьому сприяє низка проблем, із якими воно зіштовхується, головною 3 яких $є$ розробка соціальних проектів на основі західних технологій без урахування власного досвіду та особливостей сучасного розвитку. Причиною цього $є$ те, що практика соціального проектування запозичена із Заходу. I в перші роки іiі використання не вистачало відповідного досвіду у цій сфері, саме тому соціальні проекти розроблялися за західною аналогією та 3 використанням запозичених технологій. Це призводило до зниження ефекту від впровадження даних проектів. Звісно, при розробці соціального проекту передусім необхідно звертати увагу на особливості розвитку держави на певному етапі, а також не виключати аналіз та використання власного історичного досвіду. Але, на жаль, розробники проектів не завжди могли забезпечити виконання цієї вимоги (Нагорна, 2015).

В. Курбатов зауважував, що в основу соціального проектування мають бути закладені такі параметри: суперечливість соціального об'єкту; багатовекторність розвитку соціального об'єкту; множинність факторів його буття; суб'єктивні складові формування соціального очікування та прогнозу; фактори, що визначають різні критерії оцінки соціального об'єкту (Курбатов, 2001). Соціальне проектування - це проектування соціальних об'єктів, якостей, процесів i відношень.

Науковці (Старшинова, 2018) до характеристик соціального проектування відносять: інноваційність (проектування спрямоване на створення нових об'єктів, перетворення реальності); технологічність (проектування будується на основі існуючих соціально-культурних практик і має певну послідовність дій); універсальність (проектні технології входять в якості складової в усі види практик). Різновидом педагогічного проектування є особистісне проектування, метою якого є формування особистісного проекту життєвого шляху.

Важливими для нашого дослідження $є$ погляди В. Багрій щодо осмислення використання проектування як педагогічної технології у формуванні проектної культури. Науковець зауважує, що соціокультурна ситуація в суспільстві 
спричинила переосмислення еволюції освітніх процесів з позиції інтеграції освіти і культури. Проектний метод в освіті дозволяє вирішити проблеми зацікавленості студентів у самостійному утворенні, навчанні навичок проектування своєї діяльності та формування рефлексивної позиції. Процес підготовки конкурентоспроможних фахівців заснований на гуманістичному, культурологічному, особистісно орієнтованому та комунікативно-діяльнісному підходах. Серед використовуваних методів, що забезпечують системну інтеграцію фундаментальних знань та практичної діяльності, в освітньому процесі вищої школи особливе місце відводиться проектуванню (Багрій, 2014).

Серед основних факторів соціокультурного проектування В. Багрій виокремлює проектну культуру. Проектна культура визначена дослідником як єдність знань, здібностей до проектування, цінностей, цілей, управлінських та організаційних відносин, прояви соціальної активності та творчої проектної діяльності, спрямованої на вирішення соціально значущих проблем. Мета формування проектної культури особистості студентів конкретизується нами в постановці і розв'язанні наступних педагогічних завдань: свідоме засвоєння знань про соціальне проектування та соціальні інноваційні процеси, що відбуваються в країні, концепції інноваційного соціального розвитку, теорії управління, менеджменту проектів, соціальних програм; розвиток здатності до соціального проектування як якості, властивої кожній особистості, що припускає їі успішне функціонування в соціумі; формування особистого ціннісного ставлення до проектування, позитивного і зацікавленого ставлення до вирішення соціальних проблем, прояв соціальної активності та відповідальності; цілепокладання визначення ієрархії цілей проектної діяльності; розвиток суспільних відносин, насамперед управлінських, організаційних, в яких матеріалізуються знання, норми, зразки; мотивація творчої діяльності у сфері управління соціальним розвитком регіону, котра має творчий характер, що дозволяє формувати як саму особистість, так і іiі культуру, норми поведінки, мотиви до інноваційної діяльності; становлення поваги в суспільстві до суспільних інститутів, держави, законів; розробка та впровадження проектних технологій, що оптимізують сам процес соціального проектування і об'єднують в одне ціле спеціальні знання про соціальне проектування, відносини, творчу діяльність і роботу громадських інститутів (Багрій, 2014).

В. Шкуро, розглядаючи передумови виникнення соціального проектування, виокремлює: потребу у зміні і розвитку тих чи інших соціальних систем або соціальних об'єктів; соціальну необхідність у подоланні стихійного розвитку соціальних процесів і забезпечення їх спрямованості у задоволенні соціальних потреб; потребу у реалізації соціальної творчості; соціальну необхідність керованому розвитку соціальних систем i процесів; потребу у створенні 
соціальних систем, які характеризуються збалансованістю відносин усередині системи і гармонізацією відносин з іншими системами; орієнтацію на оптимальні форми буття соціальної системи, іiі ефективності, раціональності; соціальну потребу в зниженні рівня соціальної деструкції, рівня неорганізованості і нестабільності (Шкуро, 2012).

Класифікуючи соціальне проектування науковці вирізняють такі підходи: об'єктивно-орієнтований підхід - перевага надається розробці проектів об'єктивної реальності з локалізацією соціально-проектної діяльності та чіткого опрацювання нормативних вимог, проблемно-орієнтований підхід - вироблення варіантних зразків рішень поточних i перспективних соціально значущих проблем і суб'єктивно-орієнтований підхід (Луків, 2000). Означені підходи до класифікації проектів дозволяють визначити базові ознаки проектів соціальних, до яких (Безпалько, 2010) зараховують: цілепокладання; соціальнодетерміновану, часову, територіальну, соціально-інституційну, інноваційну, ресурсну, організаційну, соціально-інформаційну складові.

\section{Висновки та перспективи подальших досліджень}

Таким чином, серед використовуваних методів, що забезпечують системну інтеграцію фундаментальних знань та практичної діяльності, в освітньому процесі вищої школи особливе місце відводиться проектуванню. Проектний метод в освіті дозволяє вирішити проблеми зацікавленості студентів у самостійному утворенні, навчанні навичок проектування своєї діяльності та формування рефлексивної позиції. В основу соціального проектування мають бути закладені такі фактори: суперечливість соціального об'єкту; багатовекторність розвитку соціального об'єкту; множинність факторів його буття; суб'єктивні складові формування соціального очікування та прогнозу; фактори, що визначають різні критерії оцінки соціального об'єкту. Перспективу подальших досліджень вбачаємо у дослідженні ефективності умов упровадження проектної діяльності у підготовці фахівців соціономічних професій.

\section{Література}

Багрій, В.Н. (2014). Соціальне проектування як педагогічна технологія проектної культури студентів. Наукові записки НДУ ім. М. Гоголя Психологопедагогічні науки. № 3. C.86-90. URL: irbis-nbuv.gov.ua/cgi-bin/irbis_nbuv/cgiirbis_ 64.exe?...2....

Безпалько, О. В. (2010). Соціальне проектування: навчальний посібник. К.: [б. в.]. 127 с. Режим доступу: http://www.twirpx.com/file/1338287/.

Бибик, Д. Д. (2016). Соціальне проектування в структурі професійної підготовки майбутніх соціальних працівників. Актуальні дослідження в соизільній сфері : матеріали восьмої міжнародної науково-практичної 
конференції (м. Одеса, 17 листопада 2016 р.) / гол. ред. В.В.Корнещук. Одеса: ФОП Бондаренко М.О., С.263-265.

Бирюкова, М. В. (2001). Социальное проектирование и социальные технологии. Х., $400 \mathrm{c}$.

Борзенко-Мірошніченко, А. Ю. (2007). Моніторинг якості освітніх проектів на основі моделей системної динаміки: автореф. дис... канд. техн. наук: 05.13.22; Київ. нац. ун-т буд-ва і архіт. К., 20 с.

Дронова, І. В. (2004). Моделі і методи управління проектами на ринку освітніх послуг (в умовах інтеграції економіки України у єдиний європейський простір): автореф. дис... канд. техн. наук: 05.13.22; Нац. аерокосм. ун-т ім. М.Є.Жуковського «Харк. авіац. ін-т». Х., 20 с.

Клешня, Г. М. (2017). Соціальне проектування як спосіб майбутньотворення в інформаційному суспільстві. Вісник НАУ. Серія: Філософія. Культурологія. № 1(25). C.53-57.

Курбатов, В. И., Курбатова, О. В. (2001). Социальное проектирование: учебное пособие. Ростов н/Д.: Фенікс, 416 с.

Луков, В. А. (2003). Социальное проектирование: учеб. пособие. 3-е изд., перераб. и доп. М.: Изд-во Моск. гуманит.-социальн. академии: Флинта, $240 \mathrm{c}$.

Нагорна, Г. О. (2015). Використання соціального проектування у процесі підготовки та реалізації державних реформ. Ефективність держсвного управління. Bun. 42. С. 94-99.

Нагорна, Г. О. (2016). Соціальне проектування: історія становлення та розвитку. Молодий вчений. оㅡ 5 (32) травень. С.451-454.

Перфільєва, М.В. (2019). Соціальне проектування як один 3 найбільш актуальних напрямів у практиці соціальної роботи. URL: http://dspace.udpu.edu.ua:8181/jspui/handle/6789/3435.

Пришляк, О. (2018). Формування міжкультурної компетентності майбутніх фахівців соціономічних професій: системно-синергетичний підхід, Social Work and Education, Vol. 3, No. 1., pp. 46-55.

Рижанова, А. О. (2005). Розвиток соціальної педагогіки в соціокультурному контексті: автореф. дис... д-ра пед. наук: 13.00.05; Луган. нац. пед. ун-т ім. Т. Шевченка. Луганськ, 44 с.

Роганова, М. В. (2019). Соціальне проектування у вищому навчальному закладі інноваційного типу. URL: irbis-nbuv.gov.ua/cgibin/irbis_nbuv/cgiirbis_64.exe?...2.

Соціальне проектування. (2019). URL: https://stud.com.ua/55288/sotsiologiya/ sotsialne_proektuvannya

Тюптя, Л. Т. \& Іванова, І. Б. (2005). Соціальна робота: Теорія і практика. URL: http://westudents.com.ua/knigi/564-sotsalna-robota-tyuptya-lt.html5

Шкуро, В. П. (2012). Підвищення якості реалізації соціальних проектів. Науковий вісник Миколаӥвського наиіонального університету імені В. О. Сухомлинського. Т. 2. Вип. 9. (Серія: Психологічні науки). С. 265-269. . 


\title{
SOCIAL DESIGN TECHNOLOGIES IN THE SPECIALISTS' SOCIONOMIC PROFESSIONS TRAINING
}

\author{
Olena Zharovska, Candidate of Pedagogical Sciences, Department of Psychological \\ and Pedagogical Education and Social Sciences, Vinnytsya Academy of Continuing \\ Education, Vinnytsya, Ukraine
}

\begin{abstract}
The article substantiates the necessity of generalization and systematization of scientific ideas about design, obtained in the problem field of social work as a science with the purpose of further introduction of social designing into the specialists training process in the sociological professions. In the study, the designation of the designing options as the designing variants for optimal future object state and for making decisions under uncertainty conditions is taken as the basis. The purpose of the article is to characterize the social designing technology peculiarities implementing in the training process of specialists in socio-occupational professions. There are such methods of research as analysis, synthesis, comparison are used. The article focuses on the main goal of social projects, which ensure the fundamental knowledge integration and practical activities in the educational process of higher education. The basic features of social projects include goal-setting; social determination, temporal, territorial, social-institutional, innovative, resource, organizational, socialinformational. The research task is elaborated: to find out ways of introduction of social designing in preparation of specialists of sociological professions; To highlight the factors influencing social designing on the educational environment of higher education institution. It is noted that the characteristics of social design include: innovation (design is aimed at creating new objects, the transformation of reality); technological capacity (design is built on the basis of existing socio-cultural practices and has a certain sequence of actions); versatility (design technologies are part of all types of practices). A variety of pedagogical designing - personal design, the purpose of which is the formation of a personal project of a life path, is singled out.

The article draws attention to the fact that the basis of social design should be laid the following parameters: the contradiction of the social object; multi-vector development of a social object; multiplicity of factors of its existence; subjective components of the formation of social expectation and forecast; factors that determine different criteria for evaluating a social object. Among the main factors of sociocultural design, distinguish design culture, which is defined as the unity of knowledge, design abilities, values, goals, managerial and organizational relations, manifestations of social activity and creative project activity aimed at solving socially significant problems.
\end{abstract}


Keywords: social designing; project technology; social work; design culture; sociooccupational profession.

\section{References}

Bagrij, V. N. (2014) Social designing as a pedagogical technology for student design culture. Naukovi zapy`sky` NDU im. M. Gogolya Psy`xologo-pedagogichni nauky`.\# 3. S.86-90 URL : irbis-nbuv.gov.ua/cgi-bin/irbis_nbuv/cgiirbis_64.exe?...2... [in Ukrainian].

Bezpal ko, O. V. (2010) Social designing. Study guide. K., 27 s. [in Ukrainian].

By`by`k, D. D. (2016) Social design in the structure of the future social workers training. Actual research in the social sphere: materials of the eighth international scientific and practical conference (Odesa, November 17, 2016) / gol. red. V. V. Korneshhuk. Odesa: FOP Bondarenko M. O, S. 263-265 / URL : http://enpuir.npu.edu.ua/handle/123456789/14484/ [in Ukrainian].

Birjukova, M. V. (2001). Social designing and social technologies. H., 400 s. [in Russian].

Borzenko-Miroshnichenko, A. Yu. (2007). Monitoring of the projects development on the basis of system dynamics models: Author's abstract. dis ... cand. tech. of science: 05.13.22; Ky`yiv. nacz. un-t bud-va i arxit. K., 20 s. [in Ukrainian].

Dronova, I. V. (2004). Models and methods of projects managing on the market of the most important services (under conditions of Ukraine's economics integration into the common European one) 05.13.22; Nacz. aerokosm. un-t im. M.Ye.Zhukovs 'kogo "Xark. aviacz. in-t". X., 20 s. [in Ukrainian].

Kleshnya, G. M. (2017). Social designing as a way to the future creation in the information society. Visny`k NAU. Seriya: Filosofiya. Kul turologiya. No 1 (25). S. 5357. URL: http://er.nau.edu.ua:8080/handle/NAU/29591. [in Ukrainian].

Kurbatov, V. I. \& Kurbatova, O. V. (2001). Social designing. Study guide. Rostov n/D.: Feniks, 416 s. [in Russian].

Lukov, V. A. (2003). Social designing: Ucheb. posobie. 3-e izd., pererab. i dop. M.: Izd-vo Mosk. gumanit.-social'n. akademii: Flinta. [in Russian].

Nagorna, G. O. (2015). The social designing usage in the process of state reforms preparation and implementation. Effectiveness of public administration Vy`p. 42. «Efekty`vnist' derzhavnogo upravlinnya» S. 94-99 URL: www.lvivacademy.com/vidavnitstvo_1/edu_42/fail/12.pdf/ [in Ukrainian].

Nagorna, G. O. (2016). Social designing: formation and development history. Molody`j vcheny`j. No 5 (32) traven`, S.451-454. URL: http://molodyvcheny.in.ua/files/journal/2016/5/113.pdf/ [in Ukrainian]. 
Perfil yeva, M. V. (2019). Social designing as one of the most relevant areas in the practice of social work URL : http://dspace.udpu.edu.ua:8181/jspui/handle/6789/3435/ [in Ukrainian].

Pryshlyak, O. (2016). Formation of intercultural competence for future specialists of socio-occupational professions: system-synergetic approach. Social work and education, 3(1), P. 46-55.

Ry'zhanova, A. O. (2005). The social pedagogy development in the socio-cultural context: Author's abstract. Dis ... Dr. Ped. Sciences:13.00.05 / A.O. Ry`zhanova ; Lugan. nacz. ped. un-t im. T.Shevchenka. Lugans`k, 44 s. [in Ukrainian].

Roganova, M. V. (2019). Social designing in a higher educational institution of an innovative type.URL : irbis-nbuv.gov.ua/cgi-bin/irbis_nbuv/cgiirbis_64.exe?...2. [in Ukrainian].

Social designing. (2019). URL: https://stud.com.ua/55288/sotsiologiya/ sotsialne_proektuvannya. [in Ukrainian].

Tyuptya, L. T. \& Ivanova, I. B. (2005). Social work: Theory and practice. URL: http://westudents.com.ua/knigi/564-sotsalna-robota-tyuptya-lt.html5. [in Ukrainian].

Shkuro, V. P. (2012). Improving the quality of social projects implementation.. Naukovy`j visny`k My`kolayivs`kogo nacional`nogo universy`tetu imeni V. O. Suxomly`n``kogo. T. 2. Vy`p. 9. (Seriya: Psy`xologichni nauky`). S. 265-269. URL: http://nbuv.gov.ua/j-pdf/Nvmdups_2012_2_9_54.pdf. [in Ukrainian]. 